\title{
PERSEPSI PEREMPUAN TENTANG PERANNYA DALAM RUMAH TANGGA PEMBUDIDAYA KERANG HIJAU
}

\author{
Women Perception as Cockle Cultivator Households
}

\author{
Aminia Novriani* ${ }^{*}$ dan Anna Fatchiya \\ Departemen Sains Komunikasi dan Pengembangan Masyarakat, Fakultas Ekologi Manusia, IPB \\ *) Email : aminianovriani@gmail.com
}

Diterima 22 September 2011 / Disetujui 23 November 2011

\begin{abstract}
Sustainable development of coastal and marine resources in Indonesia reveals that women take an important role in coastal and marine sectors. This study focused on women's perception of their role. It aimed to assess the women's perception about their role and to analyze the relationship between internal and external factors with women's perception about their role in cockle cultivator households. This study applied survey method with quantitative approach which is supported by qualitative information. The result of this study found that most respondents are in middle adulthood (31-50 years), have low education levels, low income levels, has a job as "pengitrik" and Bugis tribes. The results of descriptive analysis showed that women's perception of their role in the household tend to be less good, it means respondents did not have a conscious view of gender in almost aspects of household roles. The results of statistical analysis showed that internal factors which is income level and employment has significantly related to women's perceptions about their role in the household. Another factors such as age, education, and income has not significantly related to the women's perception. External factors in this study such as husband's age, husband's education level and husband's income level is not significantly related to the women's perception of their role in the household.
\end{abstract}

Keywords: women's perception, cockle cultivator households, gender.

\begin{abstract}
ABSTRAK
Pembangunan berkelanjutan sumber daya pesisir dan laut di Indonesia mengungkapkan bahwa perempuan mengambil peran penting dalam sektor pesisir dan kelautan. Penelitian ini difokuskan pada persepsi perempuan dari peran mereka. Penelitian ini bertujuan untuk menilai persepsi perempuan tentang peran mereka dan menganalisis hubungan antara faktor-faktor internal dan eksternal dengan persepsi perempuan tentang peran mereka dalam rumah tangga pembudidaya kerang hijau. Penelitian ini menggunakan metode survei dengan pendekatan kuantitatif yang didukung oleh informasi kualitatif. Hasil penelitian ini menemukan bahwa sebagian besar responden berada di tengah usia dewasa (31-50 tahun), memiliki tingkat pendidikan yang rendah, tingkat pendapatan rendah, memiliki pekerjaan sebagai "pengitrik" dan suku bugis. Hasil analisis deskriptif menunjukan bahwa persepsi perempuan dari peran mereka dalam rumah tangga cenderung kurang baik, artinya responden tidak memiliki pandangan yang sadar gender dalam aspek peran rumah tangga. Hasil analisis statistik menunjukkan bahwa faktor internal yang tingkat pendapatan dan kesempatan kerja telah secara signifikan berkaitan dengan persepsi perempuan tentang peran mereka dalam rumah tangga. Faktor lain seperti usia, pendidikan, dan pendapatan tidak berhubungan secara signifikan dengan persepsi perempuan. Faktor eksternal dalam penelitian ini seperti usia suami, tingkat pendidikan suami dan tingkat pendapatan suami tidak berhubungan secara signifikan dengan persepsi perempan dari peran mereka dalam rumah tangga.
\end{abstract}

Kata kunci: persepsi perempuan, rumah tangga pembudidaya kerang hijau, gender. 


\section{PENDAHULUAN}

Indonesia merupakan salah satu negara kepulauan terbesar di dunia yang terdiri dari 17.508 pulau dengan panjang garis pantai sekitar $81.000 \mathrm{~km}$ dan luas laut sekitar 3,1 juta $\mathrm{km}^{2}\left(0,3\right.$ juta $\mathrm{km}^{2}$ perairan teritorial dan 2,8 juta $\mathrm{km}^{2}$ perairan nusantara) (Dahuri et al., 2001). Wilayah pesisir dan lautan beserta sumber daya yang terkandung di dalamnya merupakan tumpuan harapan bangsa mengingat wilayah pesisir dan lautan Indonesia mencakup 63\% wilayah teritorial Indonesia yang di dalamnya terkandung sumber daya alam dan jasa-jasa lingkungan yang kaya dan beragam, seperti perikanan, terumbu karang, hutan mangrove, minyak dan gas, bahan tambang dan mineral, serta kawasan pariwisata. Oleh karena itu, perlu adanya pengelolaan wilayah pesisir untuk menjaga keberlanjutan sumber daya tersebut.

Menurut Zubaedi (2007), peran serta dalam mengelola wilayah pesisir bukan hanya peran serta laki-laki tetapi juga perempuan. Upaya-upaya pemberdayaan perempuan dalam konteks sekarang memang cukup signifikan untuk dilakukan. Hal ini ditunjukkan oleh beberapa hal, yakni meski saat ini pengakuan secara normatif terhadap hakhak perempuan semakin kuat, pengakuan pada tataran formalitas ternyata tidak secara otomatis diiringi dengan implementasi secara sungguh-sungguh di lapangan. Selain itu, kultur sehari-hari masyarakat Indonesia yang umumnya masih melekat kuat, seperti stereotip atau pelabelan terhadap kelompok perempuan yang cenderung memarjinalkan perempuan. Situasi tersebut berdampak pada masih rendahnya partisipasi perempuan dalam pengambilan keputusan serta masih rendahnya akses dan kontrol perempuan terhadap sumber daya.

Kamal Muara merupakan salah satu wilayah pesisir di Indonesia yang memanfaatkan sumber daya pesisir berupa kegiatan pembudidayaan kerang hijau. Kegiatan ini merupakan salah satu usaha andalan masyarakatnya, di samping usaha perikanan lainnya, seperti penangkapan ikan dengan alat tangkap "bagan", "sero", pengolahan kerang hijau serta pedagang. Kegiatan budidaya kerang hijau di Kamal Muara merupakan salah satu sumber pendapatan masyarakat dan penyerapan tenaga kerja. Peran perempuan dalam rumah tangga pembudidaya kerang hijau cukup besar, yaitu peran produktif, peran reproduktif dan peran sosial.

Perempuan dengan perannya yang cukup besar dalam rumah tangga pembudidaya kerang ini, nyatanya belum banyak membuat perempuan merasa memiliki peran penting dalam rumah tangganya. Pandangan bahwa pekerjaan tersebut memang merupakan kewajiban dan tanggung jawab tidak jarang membuat perempuan menjadi dikesampingkan khususnya dalam hal pengambilan keputusan. Selanjutnya menjadi penting untuk mengetahui persepsi perempuan tentang perannya dalam rumah tangga.
Merujuk pada pemaparan di atas, maka tujuan penelitian ini antara lain: 1) mengkaji persepsi perempuan tentang perannya dalam rumah dan pembudidaya kerang hijau dan 2) menganalisis hubungan faktor internal dan eksternal terhadap persepsi perempuan tentang perannya dalam rumah tangga pembudidaya kerang hijau.

\section{TINJAUAN PUSTAKA DAN KERANGKA PEMIKIRAN}

\section{Tinjauan Pustaka}

\section{Konsep Persepsi}

Persepsi dapat didefinisikan dari berbagai sudut pandang. Menurut pengertian psikologis, persepsi adalah proses pengorganisasian, penginterpretasian terhadap stimulus yang diterima oleh individu sehingga merupakan sesuatu yang berarti dan merupakan aktivitas yang terpadu dalam diri individu. Aktivitas yang terpadu diartikan sebagai peran aktif seluruh apa yang ada dalam diri individu dalam mempengaruhi persepsi, seperti perasaan, pengalaman, kemampuan berpikir, kerangka acuan dan aspek lainnya (Davidoff, 1981 dalam Walgito, 2001). Desirato (1976) dalam Rakhmat (2003) menjelaskan persepsi adalah pengalaman tentang objek, peristiwa, atau hubungan-hubungan yang diperoleh dengan menyimpulkan informasi dan menafsirkan pesan.

Objek persepsi dapat bermacam-macam, yaitu dapat berwujud benda-benda, situasi, dan juga dapat berwujud manusia. Bila objek persepsi berwujud benda disebut persepsi benda (thing perception) sedangkan bila objek persepsi berwujud manusia atau orang disebut persepsi sosial atau social perception (Heider, 1958 dalam Walgito, 2001).

Menurut Leavitt (1978), persepsi selektif adalah salah satu cara pertahanan yang digunakan oleh individu untuk menghindari sesuatu hal yang tidak mengenakan, yaitu pertahanan terhadap masuknya hal-hal yang belum diseleksi yang agak mengganggu keseimbangan (equilibrium) seseorang. Kaidah keseluruhan tentang persepsi yang selektif adalah 1) orang melihat kepada halhal yang mereka anggap akan membantu memuaskan kebutuhan-kebutuhan; 2) mengabaikan hal-hal yang mengganggu dan kemudian; 3) melihat kepada gangguangangguan yang berlangsung lama dan yang meningkat.

\section{Faktor-faktor yang Mempengaruhi Persepsi}

Faktor-faktor yang mempengaruhi persepsi dipaparkan oleh Osley (1972) dalam Nurlia (2006), diantaranya: 1) faktor ciri-ciri khas dari objek stimulus, meliputi nilai, arti emosional, dan intensitas derajat kesadaran seseorang mengenai stimuli tersebut; 2) faktor pribadi, yaitu ciri khas individu, seperti minat, emosi, dan lainnya; 3) faktor pengeruh kelompok adalah orang lain yang dapat memberikan arah kepada sesuatu yang menentukan persepsi dan sikap pada inovasi; 4) faktor perbedaan latar belakang kultural. 
Sarwono (1999) menjelaskan bahwa persepsi seseorang dipengaruhi faktor internal dan eksternal, yakni 1) faktor internal adalah faktor-faktor yang terdapat dalam diri individu, seperti jenis kelamin, usia, tingkat pendidikan, dan tingkat pengetahuan; 2) faktor eksternal adalah faktor yang berasal dari lingkungan luar individu yang mempengaruhi persepsi seseorang, seperti lingkungan sosial budaya, interaksi antar individu dan media komunikasi.

\section{Masyarakat Pesisir}

Masyarakat pesisir adalah sekumpulan masyarakat yang hidup bersama-sama mendiami wilayah pesisir, membentuk dan memiliki kebudayaan yang khas yang terkait dengan ketergantungan pada pemanfaaatan semberdaya pesisir (Satria, 2002).

\section{Pembudidayaan Kerang Hijau}

Seekor induk kerang hijau dapat menghasilkan sel telur sebanyak kurang lebih 1,2 juta butir. Sel telur yang telah dibuahi akan berkembang dan akhirnya menetas menjadi larva. Larva ini sifatnya planktonik dan melayang di air kemudian terbawa arus selama kurang lebih 2 minggu. Bentuk larva kerang-kerang mangalami beberapa kali perubahan bentuk (metamorfosa). Pada akhir stadium larva, kerang hijau akan mengalami perubahan cara hidupnya dari planktonik menjadi sessil (tinggal diam, menempel). Pada saat-saat tersebut, bila kerang tersebut tidak dapat menemukan substrat maka mereka akan segera mati. Adapun tahap pembudidayaan kerang hijau antara lain pengumpulan benih dan pembesaran (Deptan, 1985).

\section{Konsep Gender}

Handayani dan Sugiarti (2008) menjelaskan bahwa konsep gender adalah sifat yang melekat pada kaum lakilaki dan perempuan yang dibentuk oleh faktor-faktor sosial maupun budaya sehingga lahir beberapa anggapan tentang peran sosial dan budaya laki-laki dan perempuan. Gender membedakan peran antara laki-laki dan perempuan berdasarkan kedudukan, fungsi dan peranan masing-masing dalam berbagai bidang kehidupan dan pembangunan.

Hubeis (2010) mengungkapkan peran gender untuk perempuan dan laki-laki diklasifikasikan dalam tiga peran pokok, yaitu peran reproduktif, peran produktif dan peran sosial. Peran reproduktif (domestik) adalah peran yang dilakukan oleh seseorang untuk melakukan kegiatan yang terkait dengan tugas-tugas kerumahtanggaan (berbelanja, memelihara kesehatan dan gizi keluarga, mengasuh dan mendidik anak). Pekerjaan produktif menyangkut pekerjaan menghasilkan barang dan jasa untuk dikonsumsi dan diperdagangkan (pertanian, nelayan, pekerjaan dan wirausaha). Peran Sosial merupakan peran masyarakat terkait dengan kegiatan jasa dan partisipasi politik.

\section{Analisis Gender}

Sumartuti dan Wahyuni (2004) dalam Hadiprakoso (2005) menjelaskan bahwa secara garis besar terdapat tiga kategori alat yang dapat menganalisis situasi dan posisi gender di dalam masyarakat dan keluarga, yaitu: 1) Kerangka Harvard; 2) Kerangka Moser; 3) Kerangka Pemberdayaan. Perbedaan ketiganya dapat terlihat dari Tabel 1 .

Tabel 1. Tiga Alat Analisis Gender

\begin{tabular}{|c|c|c|}
\hline $\begin{array}{l}\text { Kerangka } \\
\text { Harvard }\end{array}$ & Kerangka Moser & $\begin{array}{c}\text { Kerangka } \\
\text { Pemberdayaan }\end{array}$ \\
\hline $\begin{array}{l}\text { - Pembagian kerja: } \\
\text { produktif, } \\
\text { reproduktif, dan } \\
\text { sosial budaya } \\
\text { - Akses dan kontrol } \\
\text { terhadap sumber } \\
\text { daya dan } \\
\text { manfaat, } \\
\text { - Faktor-faktor } \\
\text { yang } \\
\text { mempengaruhi } \\
\text { peranan dalam } \\
\text { masyarakat } \\
\text { Alat ini dapat } \\
\text { digunakan untuk } \\
\text { alat analisis situasi } \\
\text { sebelum membuat } \\
\text { perencanaan } \\
\text { program } \\
\text { pembangunan }\end{array}$ & $\begin{array}{l}\text { - Pembagian } \\
\text { peran: produktif, } \\
\text { reproduktif, dan } \\
\text { sosial budaya } \\
\text { - Kebutuhan } \\
\text { praktis(menyang } \\
\text { kut kondisi). } \\
\text { Kebutuhan } \\
\text { strategis } \\
\text { (menyangkut } \\
\text { posisi) }\end{array}$ & $\begin{array}{l}\text { Alat untuk melihat } \\
\text { tahapan } \\
\text { pemberdayaan } \\
\text { (semakin bertahap } \\
\text { ke arah dari } \\
\text { kesejahteraan } \\
\text { sampai } \\
\text { penguasaan) } \\
\text { menggambarkan } \\
\text { adanya } \\
\text { peningkatan } \\
\text { pemerataan dan } \\
\text { pemampuan }\end{array}$ \\
\hline
\end{tabular}

Sumber: Hadiprakoso, 2005

Kerangka Harvard akan digunakan dalam penelitian ini. Handayani dan Sugiarti (2008) menjelaskan bahwa teknik analisis ini dirancang sebagai landasan untuk melihat suatu profil gender dari suatu kelompok sosial.

\section{Akses dan Kontrol terhadap Sumber Daya dan Manfaat}

Handayani dan Sugiarti (2001) menyebutkan bahwa akses adalah peluang yang bisa diperoleh laki-laki dan perempuan untuk memiliki atau menikmati sesuatu (pekerjaan, kegiatan, barang, jasa). Sementara kontrol adalah sejauh mana perempuan dan laki-laki mempunyai kekuasaan atau kemampuan dalam proses pengambilan keputusan dalam merencanakan, melakukan, memiliki atau menikmati sesuatu. Laki-laki dan perempuan yang akses terhadap sumber daya tertentu belum tentu memiliki kontrol terhadap sumber daya tersebut. Hal tersebut disebabkan akses seseorang ditentukan oleh orang lain sementara kontrol mencirikan bahwa seseorang itu berkuasa atau tidak untuk menentukan sumber daya yang diakses atau tidak diakses. 


\section{Kerangka Pemikiran}

Kamal Muara merupakan salah satu wilayah pesisir di Indonesia yang memanfaatkan sumber daya pesisir berupa pembudidayaan kerang hijau. Kegiatan budidiya ini telah berlangsung lama dan menjadi mata pencaharian utama bagi masyarakatnya. Peran perempuan yang dalam hal ini adalah istri tidak hanya dalam kegiatan produktif ini, tetapi juga reproduktif dan sosial kemasyarakatan. Masyarakat Kamal Muara didominasi oleh pembudidaya kerang yang memiliki latar belakang sosial, ekonomi dan budaya yang cukup beragam. Aspek sosial, seperti tingkat pendidikan, jenis pekerjaan, usia dan jenis kelamin; aspek ekonomi, seperti tingkat pendapatan; serta aspek budaya, yaitu suku akan dilihat hubungannya terhadap terhadap persepi perempuan tentang perannya dalam rumah tangga. Ketiga aspek tersebut akan dikelompokkan menjadi faktor internal dan faktor eksternal. Hal tersebut dapat dilihat pada Gambar 1.

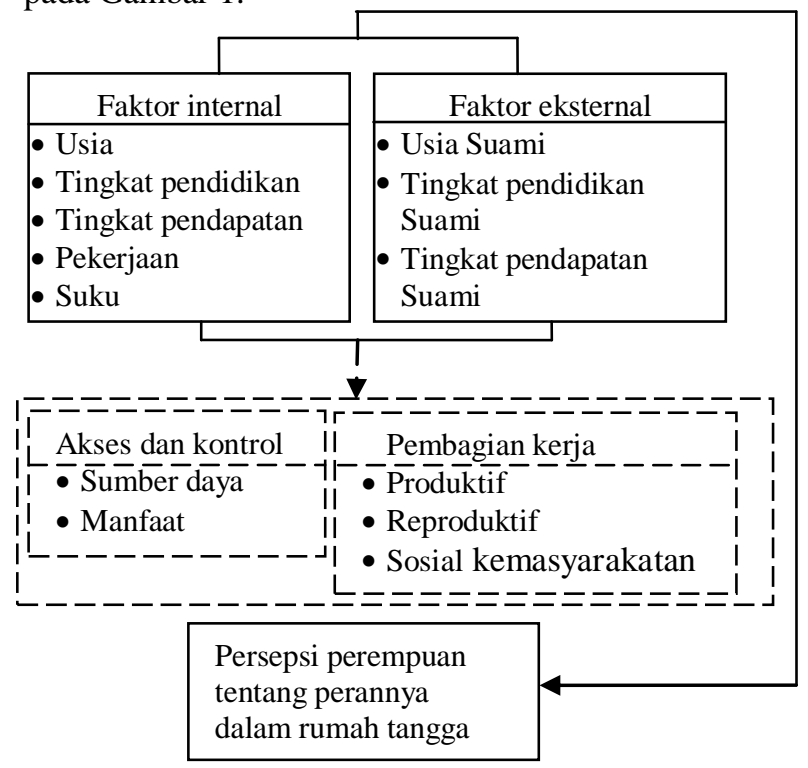

Keterangan:

$$
\begin{aligned}
& \longrightarrow \text { Diteliti } \\
& \text { melihat persepsi }
\end{aligned}
$$

Gambar 1. Kerangka Pemikiran Penelitian

\section{Hipotesis Penelitian}

Berdasarkan kerangka pemikiran dapat disusun hipotesis sebagai berikut:

1. faktor internal usia responden signifikan berhubungan dengan persepsi perempuan tentang perannya dalam rumah tangga;

2. faktor internal tingkat pendidikan responden signifikan berhubungan dengan persepsi perempuan tentang perannya dalam rumah tangga;

3. faktor internal tingkat pendapatan responden signifikan berhubungan dengan persepsi perempuan tentang perannya dalam rumah tangga;
4. faktor internal perkerjaan responden berhubungan nyata dengan persepsi perempuan tentang perannya dalam rumah tangga;

5. faktor internal suku responden berhubungan nyata dengan persepsi perempuan tentang perannya dalam rumah tangga;

6. faktor eksternal usia suami signifikan berhubungan dengan persepsi perempuan tentang perannya dalam rumah tangga;

7. faktor eksternal tingkat pendidikan suami signifikan berhubungan dengan persepsi perempuan tentang perannya dalam rumah tangga;

8. faktor eksternal tingkat pendapatan suami signifikan berhubungan dengan persepsi perempuan tentang perannya dalam rumah tangga.

\section{PENDEKATAN LAPANGAN}

\section{Metode Penelitian}

Tipe penelitian explanatory adalah menganalisis data dengan cara menjelaskan hubungan kausal antar peubahpeubah melalui pengujian hipotesis. Pendekatan kuantitatif menggunakan metode survei dimana data diperoleh dari sampel atas populasi untuk mewakili seluruh populasi dengan menggunakan kuesioner (Singarimbun dan Effendi, 1989). Pendekatan kualitatif dalam penelitian ini dilakukan dengan metode wawancara mendalam dan pengamatan langsung di lokasi penelitian.

\section{Lokasi dan Waktu}

Penelitian ini dilakukan di dua RW, yaitu RW 1 dan RW 4 Kelurahan Kamal Muara, Kecamatan Penjaringan, Jakarta Utara. Lokasi ini dipilih secara sengaja dengan per-timbangan bahwa dari enam RW yang terdapat di Kamal Muara, hanya RW 1 dan RW 4 yang menjadi lokasi pembudidayaan kerang hijau. Pengumpulan data primer dan data sekunder dilakukan pada bulan April 2011 dan dilanjutkan dengan pengolahan data dan penulisan laporan pada Mei-Agustus 2011.

\section{Teknik Pengumpulan Data}

Data yang digunakan adalah data primer dan data sekunder. Data primer diperoleh dari pengumpulan data melalui instrumen utama, yaitu kuesioner yang telah disusun. Populasi dalam penelitian ini adalah seluruh perempuan yang berperan sebagai istri dalam rumah tangga yang memiliki secara pribadi usaha pembudidayaan kerang hijau. Unit analisis dalam penelitian ini adalah individu, yaitu istri dari rumah tangga yang memiliki dan melakukan kegiatan pembudidayaan kerang hijau. Pemilihan responden dilakukan dengan teknik nonprobability sampling, yaitu Haphazard sampling atau accidental sampling yang mempertahankan kelayakan dan ketepatan sampel yang dipilih (Jogianto, 2008).

Responden dipilih secara sengaja dengan pertimbangan bahwa responden tersebut sebagai rumah tangga yang memiliki secara pribadi usaha pembudidayaan kerang hijau sehingga dapat mengambil keputusan secara 
mandiri. Pengambilan keputusan tersebut diasumsikan dapat merepresentasikan sejauh mana keterlibatan perempuan dalam rumah tangganya. Jumlah responden dalam penelitian ini sebanyak 40 responden yang ditemui secara insidental. Teknik yang digunakan dalam memilih informan adalah purposive, yaitu seseorang yang dianggap memahami keadaan dan kondisi sosial penduduk serta usaha pembudidayaan kerang hijau. Informan yang dipilih adalah Wakil Lurah Kamal Muara, Ketua RW 04, istri ketua RW 04 dan dua orang “juragan” kerang hijau.

\section{Teknik Pengolahan dan Analisis Data}

Data kuantitatif yang telah diperoleh dianalisis secara deskriptif dan inferensial. Langkah awal yang dilakukan adalah melakukan pengkodean terhadap kuesioner lalu menganalisisis secara deskriptif. Langkah berikutnya adalah melakukan analisis inferensial yaitu dengan Uji Korelasi Chi Square dan Rank Spearman. Chi Square digunakan untuk mengetahui hubungan antara pekerjaan dan suku responden dengan persepsinya tentang masingmasing perannya dalam rumah tangga pembudidaya kerang hijau. Rank Spearman digunakan untuk mengetahui hubungan antara usia (responden dan suami), pendidikan (responden dan suami), dan pendapatan (responden dan suami) dengan persepsi responden tentang masing-masing perannya dalam rumah tangga pembudidaya kerang hijau. Uji Korelasi Chi Square dan Rank Spearman dilakukan dengan bantuan perangkat lunak statistika yaitu SPSS versi 16.0 for Windows.

\section{GAMBARAN UMUM LOKASI PENELITIAN}

\section{Letak dan Kondisi Fisik}

Batas-batas wilayah Kelurahan Kamal Muara, yaitu sebelah utara berbatasan dengan Pantai Laut Jawa, sebelah timur berbatasan dengan Kali Cengkareng Drain, sebelah selatan berbatasan dengan sepanjang Jalan Kapuk Kamal dan sebelah barat berbatasan dengan Desa Dadap, Kabupaten Tangerang, Banten. Kelurahan Kamal Muara terdiri atas enam RW dengan penggunaan lahan yang berbeda-beda.

Tabel 2. Luas Wilayah Berdasarkan Penggunaan Lahan di Kelurahan Kamal Muara, Jakarta Utara Tahun 2011

\begin{tabular}{lcr}
\hline No $\quad$ Penggunaan Lahan & Luas (ha) & \multicolumn{1}{c}{$\%$} \\
\hline 1. Perumahan & 85,30 & 8,10 \\
2. Industri/pergudangan & 295,00 & 28,01 \\
3. Hutan lindung & 666,00 & 63,25 \\
4. Fasos dan fasum & 2,30 & 0,22 \\
5. Aset Pemda & 4,40 & 0,42 \\
Jumlah & $1.053,00$ & 100,00 \\
\hline
\end{tabular}

Kondisi lingkungan di Kelurahan Kamal Muara tergolong cukup kumuh. Rumah warga banyak yang terbuat dari anyaman bambu dan berlantai papan. Khusus di RW 1 dan RW 4, mayoritas daratan terbuat dari timbunan cangkang kulit kerang hasil buangan dari kegiatan masyarakat. Timbunan cangkang kulit kerang yang ini menimbulkan bau yang tidak sedap dan pemandangan yang kurang enak dipandang.

\section{Keadaan Penduduk, Pendidikan dan Mata Pencaharian}

Jumlah penduduk Kelurahan Kamal Muara pada periode Maret 2011 yaitu 9.093 jiwa yang terdiri dari laki-laki 4.854 jiwa $(53,38 \%)$ dan perempuan 4.239 jiwa $(46,62 \%)$. Penduduk Kamal Muara memiliki bermacam karakteristik berdasarkan usia dan jenis kelamin. Berdasarkan Gambar 2, jumlah penduduk laki-laki di setiap kelompok usia cenderung lebih banyak dibandingkan perempuan. Data kependudukan Kelurahan Kamal Muara menyebutkan bahwa jumlah penduduk perempuan berjumlah 4.239 jiwa dan penduduk laki-laki berjumlah 4.854 jiwa. Dengan demikian, didapatkan bahwa rasio jenis kelamin Kelurahan Kamal Muara adalah 114, artinya setiap 100 perempuan terdapat 114 laki-laki. Jumlah penduduk usia produktif pun lebih banyak dibandingkan usia nonproduktif. Rusli (1995) menjelas-kan bahwa usia produktif, yaitu usia 15-64 tahun, sedang-kan usia nonproduktif adalah 0-14 tahun dan lebih dari 65 tahun. Jumlah penduduk produktif berjumlah 6.402 jiwa, sedangkan jumlah penduduk nonproduktif berjumlah 2.691 jiwa. Berdasarkan data tersebut didapatkan bahwa rasio ketergantungan penduduk Kelurahan Kamal Muara adalah 42, artinya setiap 100 penduduk yang produktif menanggung beban hidup penduduk yang nonproduktif sebanyak 42 orang.

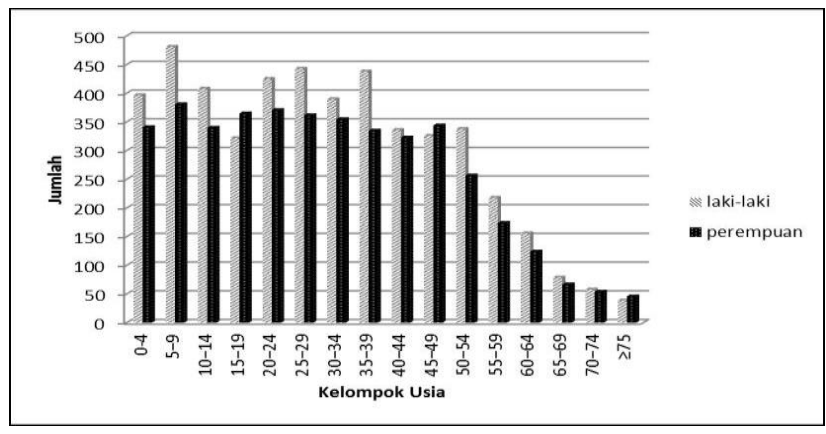

Sumber: Data Kependudukan Kelurahan Kamal Muara, 2011

Gambar 2. Distribusi Penduduk Berdasarkan Jenis Kelamin dan Kelompok Usia di Kelurahan Kamal Muara, Jakarta Utara Tahun 2011

Tingkat pendidikan penduduk Kelurahan Kamal Muara tergolong rendah. Berdasarkan hasil wawancara mendalam dengan beberapa penduduk setempat didapatkan informasi bahwa mayoritas pendidikan penduduk hanya setingkat SD, bahkan masih banyak yang tidak lulus. Pada dasarnya kesadaran penduduk mengenai pentingnya pendidikan cukup tinggi, namun karena keterbatasan biaya dan himpitan ekonomi, mereka lebih mengutamakan kebutuhan sehari-hari. Berdasarkan mata pencaharian (Gambar 3), mayoritas penduduk Kelurahan Kamal 
Muara bekerja sebagai karyawan swasta. Hal ini disebabkan banyaknya perindustrian atau pergudangan di wilayah tersebut yang memerlukan banyak tenaga kerja. Mayoritas penduduk setempat bekerja sebagai buruh karena pendidikan mereka yang rendah.

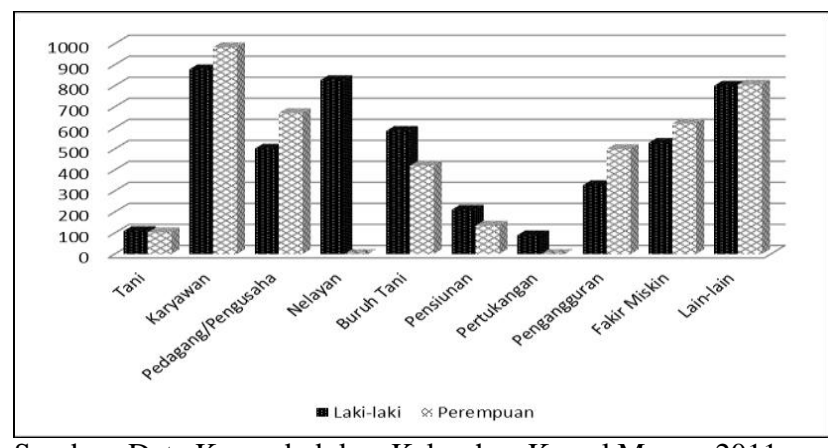

Sumber: Data Kependudukan Kelurahan Kamal Muara, 2011

Gambar 3. Distibusi Penduduk Berdasarkan Jenis Kelamin dan Pekerjaan di Kelurahan Kamal Muara, Jakarta Utara Tahun 2011

\section{Sarana dan Prasarana}

Sarana dan prasarana Kelurahan Kamal Muara tergolong cukup lengkap, antara lain sarana dan prasarana di bidang keagamaan, sosial, transportasi, kesehatan, pendidikan dan keterampilan, serta kebudayaan dan olahraga. Kegiatan di bidang keagamaan didukung dengan adanya lima masjid, tujuh mushola, sembilan majelis taklim dan dua gereja. Sarana dan prasarana transportasi dapat dilihat melalui perbaikan jalan yang dilakukan pemerintah daerah setempat. Akses menuju kelurahan ini pun tergolong mudah yaitu dapat menggunakan mobil pribadi, angkutan umum, becak, maupun ojek.

Pemerintah Kelurahan Kamal Muara bekerja sama dengan Puskesmas Kelurahan Kamal Muara memberikan pembinaan dan penyuluhan kesehatan secara langsung kepada masyarakat guna peningkatkan taraf kesehatan dan pengetahuan masyarakat mengenai kesehatan. Sarana dan prasarana lain yang menjadi fokus utama Pemerintah Kelurahan Kamal Muara adalah di bidang pendidikan dan keterampilan. Kelurahan ini memiliki tiga gedung SD atau sederajat, satu bangunan SMP, panti asuhan dan taman kanak-kanak. Bidang kesenian didukung dengan adanya perkumpulan marawis, kesenian tradisional dan Reog Ponorogo yang hingga kini masih berkembang dan berjalan dengan baik. Disamping perkumpulan kesenian, juga terdapat perkumpulan olahraga, seperti sepak bola, voli, tenis meja dan bulu tangkis. Perkumpulan olahraga ini ada di hampir setiap RW. Terdapat sebuah lapangan olahraga untuk mendukung kegemaran masyarakat di bidang olahraga.

\section{HASIL PENELITIAN}

\section{Karakteristik Responden}

Distribusi responden berdasarkan masing-masing peubah dapat dilihat pada Tabel 3 .
Tabel 3. Distribusi Jumlah dan Persentase Responden Berdasarkan Peubah Penelitian Tahun 2011

\begin{tabular}{|c|c|c|}
\hline Peubah & Jumlah & $\begin{array}{c}\text { Persentase } \\
(\%)\end{array}$ \\
\hline \multicolumn{3}{|l|}{ Usia istri } \\
\hline Dewasa awal (18-30 tahun) & 13 & 32 \\
\hline Dewasa tengah (31-50 tahun) & 26 & 65 \\
\hline Dewasa tua ( $>50$ tahun) & 1 & 3 \\
\hline \multicolumn{3}{|l|}{ Usia suami } \\
\hline Dewasa awal (18-30 tahun) & 6 & 15 \\
\hline Dewasa tengah (31-50 tahun) & 27 & 67 \\
\hline Dewasa tua (>50 tahun) & 7 & 18 \\
\hline \multicolumn{3}{|l|}{ Tingkat pendidikan istri } \\
\hline Rendah (1-3 tahun) & 7 & 17 \\
\hline Sedang (4-6 tahun) & 24 & 60 \\
\hline Tinggi ( $>6$ tahun) & 9 & 23 \\
\hline \multicolumn{3}{|l|}{ Tingkat pendidikan suami } \\
\hline Rendah (2-5 tahun) & 5 & 12 \\
\hline Sedang (6-9 tahun) & 32 & 80 \\
\hline Tinggi ( $>9$ tahun) & 3 & 8 \\
\hline \multicolumn{3}{|l|}{ Tingkat pendapatan istri } \\
\hline Rendah $(\leq \operatorname{Rp} 500.000,00)$ & 33 & 82 \\
\hline Sedang (Rp 500.001,00- & 5 & 13 \\
\hline $\operatorname{Rp} 1.000 .000,00)$ & & \\
\hline Tinggi (>Rp 1.000.000,00) & 2 & 5 \\
\hline \multicolumn{3}{|l|}{ Tingkat pendapatan suami } \\
\hline Rendah $(\leq \mathrm{RP} 2.100 .000,00)$ & 22 & 55 \\
\hline Sedang ( Rp 2.100.001,00- & 15 & 37 \\
\hline Rp 3.300.000,00) & & \\
\hline Tinggi (>Rp 3.300.000,00) & 3 & 8 \\
\hline \multicolumn{3}{|l|}{ Pekerjaan } \\
\hline IRT & 10 & 25 \\
\hline Ngitrik & 18 & 45 \\
\hline Penjual kerang & 4 & 10 \\
\hline Warung & 5 & 12 \\
\hline Tukang kredit & 3 & 8 \\
\hline \multicolumn{3}{|l|}{ Suku } \\
\hline Bugis & 24 & 60 \\
\hline Sunda & 8 & 20 \\
\hline Jawa & 4 & 10 \\
\hline Minang & 3 & 7 \\
\hline Betawi & 1 & 3 \\
\hline
\end{tabular}

\section{Usia}

Berdasarkan pengkategorian orang dewasa menurut Havighurst dan Acherman dkk. dalam Mugniesyah (2008), penelitian ini membedakan responden menjadi tiga kategori orang dewasa, yaitu dewasa awal (18-30 tahun), dewasa pertengahan (31-50 tahun), serta dewasa tua (>50 tahun). Sebagian besar responden dalam penelitian ini termasuk pada kategori dewasa tengah, yakni sebanyak 26 orang $(65 \%)$ dan hanya 1 orang $(3 \%)$ yang termasuk kategori dewasa tua. Tabel 3 juga menunjukkan bahwa sebagian besar usia suami termasuk pada kategori dewasa tengah, yakni sebanyak 27 orang $(67 \%)$.

\section{Tingkat Pendidikan}

Menurut Tabel 3 sebagian besar responden, yakni sebanyak 24 orang $(60 \%)$ berpendidikan sedang dimana responden telah menempuh pendidikan selama 4-6 tahun. Dibandingkan dengan program pemerintah Wajib Belajar 
Sembilan Tahun, tingkat pendidikan responden dalam penelitian ini tergolong rendah. Dari 40 responden, 31 orang $(77 \%)$ diantaranya berpendidikan tidak lebih dari 6 tahun. Hanya 9 orang $(23 \%)$ yang menamatkan sekolahnya hingga jenjang Sekolah Menengah Pertama. Kondisi ini menjadi tanggung jawab bersama khususnya pemerintah untuk meningkatkan pendidikan masyarakat guna mencapai salah satu sasaran pada Millenium Development Goals Indonesia yakni mencapai pendidikan dasar secara universal.

Berbeda dengan tingkat pendidikan istri, sebagian besar suami responden menempuh pendidikan formal selama 69 tahun, yakni sebanyak 32 orang $(80 \%)$. Hanya 3 orang (8\%) suami responden yang berpendidikan tinggi (menempuh pendidikan formal lebih dari sembilan tahun). Tingkat pendidikan suami lebih tinggi dibandingkan dengan tingkat pendidikan istri. Hal ini menunjukkan bahwa masih terdapat kesenjangan antara laki-laki dan perempuan.

\section{Tingkat Pendapatan}

Merujuk pada Tabel 3, pendapatan suami lebih besar dibandingkan dengan pendapatan istri. Hal ini menunjukkan bahwa kegiatan produktif memang dominan dilakukan oleh suami. Jika dibandingkan, pendapatan suami cenderung berada di atas UMR Jakarta, yakni Rp1.290.00,00. Umumnya penghasilan bersih yang dihasilkan sekitar $60-70 \%$ pendapatan kotor. Berdasarkan batas garis kemiskinan yang ditetapkan oleh Badan Pusat Statistik pada tahun 2011, yakni Rp233.740,00 per kapita/bulan, mayarakat pada penelitian ini pada dasarnya tidak tergolong masyarakat miskin karena pendapatan mereka Rp595.283,00 per kapita/bulan. Namun, jika merujuk pada 14 kriteria kemiskinan menurut BPS, rumah tangga dalam penelitian ini rata-rata memenuhi beberapa kriteria tersebut, diantaranya luas lantai bangunan tempat tinggal kurang dari $8 \mathrm{~m}^{2}$ per orang, jenis lantai bangunan tempat tinggal terbuat dari tanah/bambu/kayu murahan dan jenis dinding tempat tinggal terbuat dari bambu/ rumbia/kayu berkualitas rendah/tembok tanpa diplester.

\section{Pekerjaan Responden}

Sebagian besar responden, yaitu sebanyak 18 orang (45\%) bekerja sebagai "pengitrik" kerang, yakni membersihkan dan memisahkan kerang dari media tempelnya berupa tambang besar. Upah pekerjaan ini tidak cukup besar, untuk satu ember (volume \pm 7 liter) kerang yang telah dibersihkan dan dipisahkan dari tambangnya dihargai Rp2.000,00-Rp3.000,00. Sebanyak 3 orang (8\%) bekerja sebagai tukang kredit.

\section{Suku}

Tabel 3 menunjukkan sebanyak $60 \%$ responden bersuku Bugis. Mayoritas penduduk yang memiliki pembudidayaan kerang di RT 01 dan RT 04 bersuku Bugis. Masyarakat Bugis memang terkenal sebagai masyarakat pelaut yang memiliki mobilitas cukup besar.

\section{Persepsi Perempuan Tentang Perannya dalam Rumah Tangga Pembudidaya Kerang Hijau}

Hasil rataan skor tiap indikator mengenai persepsi perempuan tentang perannya dalam rumah tangga pembudidaya kerang hijau menunjukkan angka rata-rata sebesar 2,43 dimana hasil tersebut merepresentasikan bahwa persepsi perempuan tentang perannya dalam rumah tangga belum cukup baik, artinya sebagian responden berpandangan bahwa pembagian kerja dalam rumah tangga sudah cukup setara, padahal kondisi faktual di lapangan menemukan bahwa sebagaian besar perkerjaan dalam rumah tangga dilakukan oleh istri. Dengan demikian, dapat dikatakan bahwa responden dalam penelitian ini belum sadar gender, artinya belum menyadari bahwa perlu adanya keseteraan gender dalam rumah tangga sehingga pemahaman mereka masih perlu diperdalam. Secara umum, persepsi perempuan tentang perannya dalam rumah tangga dapat dilihat pada Tabel 4.

Tabel 4. Jumlah, Persentase dan Rataan Skor Berdasarkan Persepsi Responden Secara Keseluruhan tentang Perannya dalam Rumah Tangga Tahun 2011

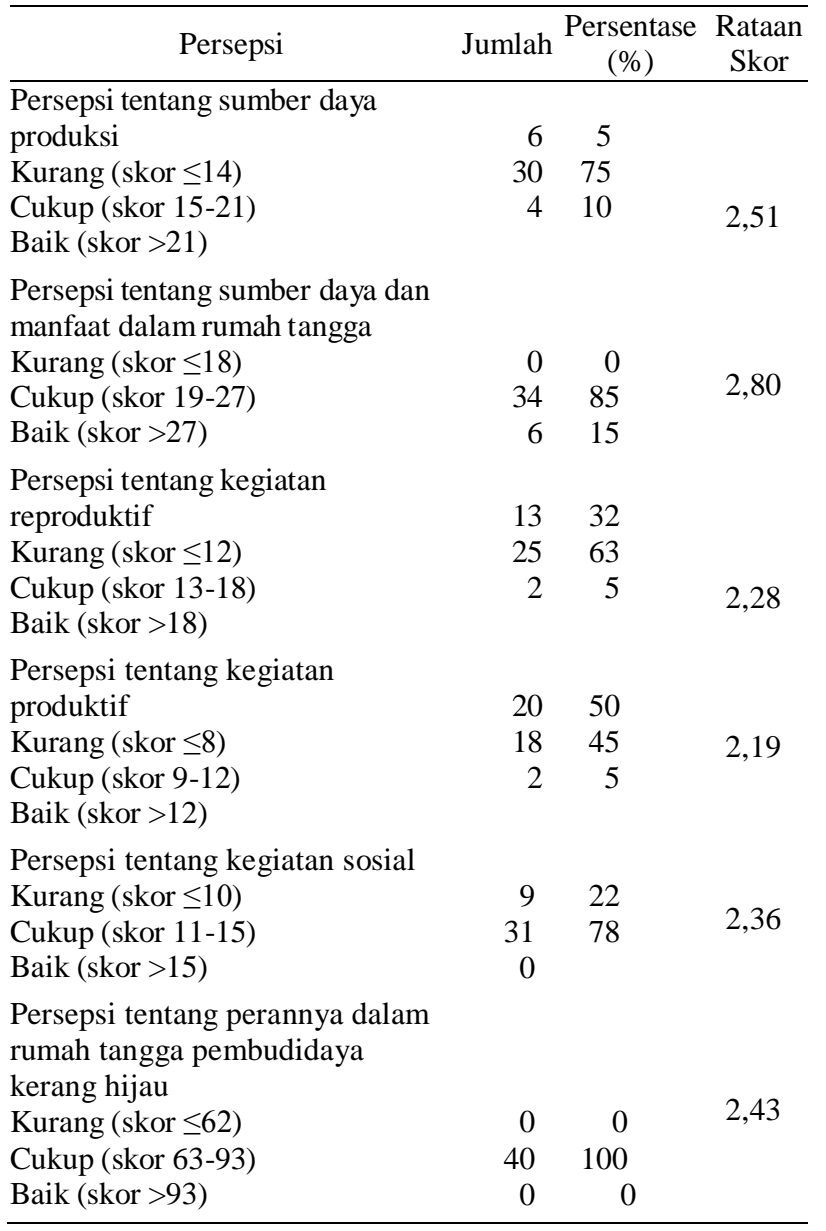

\section{Persepsi terhadap Sumber Daya Produksi}

Aspek yang digunakan untuk melihat sumber daya produksi ini antara lain pekerjaan, waktu bekerja, modal usaha, lahan usaha, pelatihan/penyuluhan dan air bersih. 
Berdasarkan hasil wawancara mendalam dengan responden didapatkan bahwa pengambilan keputusan mengenai sumber daya produksi umumnya dilakukan oleh suami. Hasil rataan skor pada sumber daya produksi yang bernilai 2,51 menunjukkan bahwa persepsi responden terhadap sumber daya produksi dalam rumah tangga pembudidaya kerang hijau masih jauh dari skor yang diinginkan, yakni 3,00. Hal ini mengidentifikasikan bahwa pemahaman responden mengenai kesetaraan gender masih perlu diperdalam agar persepsi yang terbentuk dalam diri mereka lebih positif terkait perannya dalam rumah tangga.

Berdasarkan hasil penelitian didapatkan bahwa skor persepsi pada masing-masing pernyataan tergolong belum cukup baik, yakni kurang dari 3,00. Pada pernyataan satu, dimana 47,5\% responden menjawab tidak setuju dengan pernyataan yang mengatakan bahwa hanya suami yang berhak menentukan pekerjaan istri, artinya mereka berpandangan bahwa istri berhak menentukan perkerjaan mereka sendiri. Hal ini juga didukung dengan keadaan ekonomi yang mendesak sehingga responden berpandangan bahwa jika suami tidak mengizinkan untuk bekerja, kebutuhan mereka tidak akan terpenuhi.

\section{Persepsi terhadap Sumber Daya dan Manfaat dalam Rumah Tangga}

Sumber daya dan manfaat dalam rumah tangga berkaitan dengan akses dan kontrol terhadap sumber daya dan kegiatan yang terjadi dalam sebuah rumah tangga. Pengambilan keputusan terkait penggunaan uang rumah tangga umumnya dilakukan oleh istri, namun untuk pembelian barang-barang yang bernilai cukup besar keputusan umumnya dilakukan oleh suami. Untuk melihat persepsi terdapat sumber daya dan manfaat dalam rumah tangga, penelitian ini menggunakan beberapa aspek. Pada Tabel 4 walaupun hasil rataan skor yang bernilai 2,80 dapat dikatakan lebih tinggi dibandingkan skor yang lain, namun nilai ini masih belum memenuhi skor yang diinginkan, yakni 3,00. Hal ini berarti bahwa persepsi responden terhadap sumber daya dan manfaat dalam rumah tangga tergolong belum cukup baik, artinya responden memiliki persepsi yang belum cukup sadar gender.

Terdapat beberapa pandangan yang menyatakan bahwa keuangan sepenuhnya tanggung jawab istri karena mereka menganggap bahwa suami tidak cakap dalam mengatur pengeluaran rumah tangga. Namun, untuk hal-hal besar, seperti pembelian perhiasan dan perabot rumah tangga pengambilan keputusan utama adalah suami, mereka akan membeli barang tersebut jika suami mengizinkan. Terdapat hal yang cukup bertolak belakang pada kasus ini, dimana kondisi faktual terjadi ketidaksetaraan gender, namun persepsi mereka lebih bersifat sadar gender (kesetaraan gender) yang diperkuat dengan skor yang cukup besar tersebut.
Kesimpulan yang dapat diambil, yakni responden penelitian ini pada beberapa aspek memiliki persepsi yang cukup baik, yakni bersifat sadar gender mengenai sumber daya dan manfaat dalam rumah tangganya. Namun, di beberapa aspek yang lain, pemahaman mereka mengenai kesetaraan gender masih perlu diperdalam.

\section{Persepsi terhadap Kegiatan Reproduktif}

Pekerjaan reproduktif pada umumnya dilakukan oleh istri sendiri, kecuali membetulkan rumah yang dilakukan oleh suami sendiri karena menurut responden pekerjaan tersebut tergolong cukup berat. Persepsi responden berdasarkan hasil rataan skor pada Tabel 4 adalah 2,28, yakni belum baik, artinya dalam hal kegiatan reproduktif responden cenderung menerima dan memandang bahwa perkerjaan reproduktif merupakan tugas istri. Kenyataan di lapangan pun menunjukkan bahwa hampir semua kegiatan reproduktif dikerjakan oleh istri sendiri. Selain melaut, rata-rata pekerjaan suami di rumah hanya tidur dan bersantai, sebaliknya mulai dari pagi hingga malam hari istri mengerjakan pekerjaan rumah mulai dari memasak, mencuci, membersihkan rumah hingga mengasuh anak.

Hasil rataan skor mengenai persepsi responden terhadap kegiatan reproduktif cukup merepresentasikan bahwa perempuan yang dalam hal ini adalah istri dalam rumah tangga pembudidaya kerang hijau beranggapan bahwa kegiatan reproduktif merupakan taggung jawabnya. Walaupun persepsi mereka tidak selalu setuju dengan kenyataan, namun mereka merasa bertanggung jawab penuh atas kegiatan ini.

\section{Persepsi terhadap Kegiatan Produktif}

Kegiatan produktif menyangkut pekerjaan menghasilkan barang dan jasa untuk dikonsumsi dan diperdagangkan seperti pertanian, nelayan, pekerjaan dan wirausaha (Hubeis, 2010). Berdasarkan hasil penelitian di lapangan, didapatkan bahwa pekerjaan produktif sebagai nelayan dan pembudidaya kerang hijau dikerjakan sepenuhnya oleh suami, khususnya pekerjaan di laut. Istri tidak ikut serta dengan beberapa alasan seperti tidak bersedia karena pekerjaan tersebut tergolong berat dan/atau tidak diizinkan oleh suami. Pekerjaan produktif yang dimaksud dalam penelitian ini adalah pekerjaan yang terkait dengan pembudidayaan kerang hijau.

Pekerjaan produktif terkait pembudidayaan kerang mayoritas dilakukan oleh suami. Menyiapkan media tempel dan memanen sepenuhnya dilakukan oleh suami karena dianggap sebagai pekerjaan yang tergolong berat dan sulit dilakukan oleh istri. Membersihkan kerang hijau dan menjual umumnya dilakuakn bersama oleh suami dan istri.

Hasil rataan skor pada konteks ini sebesar 2,19 dimana tergolong belum baik, artinya responden berpandangan bahwa pekerjaan produktif selayakanya dikerjakan oleh suami. Tidak jauh berbeda, Tabel 4 juga menunjukkan 
bahwa 50\% responden memiliki persepsi yang kurang mengenai kegitaan produktif ini. Responden umumnya merasa tidak perlu membantu suami dalam hal penempelan kerang dan pemanenan, jika pun membantu umumnya istri hanya membantu untuk membersihkan dan memisahkan kerang dari media tempel dan menjual. Menjual pun tergantung dari metode penjualan yang suami lakukan. Jika suami memilih menjual di laut, maka istri tidak akan dapat membantu dalam hal penjualan hasil panen. Sebagian besar responden menyatakan sangat tidak setuju jika istri juga menyiapkan media tempel dan berperan serta dalam pemanenan. Hal ini disebabkan kegiatan tersebut merupakan hal yang berat dan mereka berpandangan bahwa perempuan tidak akan sanggup mengerjakannya.

Menyiapkan media tempel adalah langkah pertama untuk membudidayakan kerang hijau. Media tempel yang digunakan umumnya adalah tambang besar berdiameter 5-6 $\mathrm{cm}$ yang selanjutnya diikatkan pada bambu-bambu yang telah disusun membentuk kotak. Setelah pemasangan media tempel ini selesai, langkah selanjutnya adalah membiarkan media tersebut hingga 3-6 bulan ke depan. Bibit kerang akan dengan sendirinya menempel dan membesar di media tempel tersebut tanpa perlu dipelihara atau diperiksa setiap hari kondisinya. Setalah besar, kerang tersebut siap dipanen. Pemanenan pun membutuhkan upaya yang besar. Ketika memanen, 2-3 orang akan menyelam ke dalam laut untuk mengangkat kerang beserta media tempelnya ke atas. Nelayan lain yang berada di perahu membantu menarik tambang dan menempatkannya ke atas perahu.

Sesampainya di daratan, barulah istri dapat membantu suami untuk membersihkan dan memisahkan kerang tersebut dari media tempelnya. Pekerjaan ini umum disebut dengan ngitrik. Satu kali pemanenan menghasil-kan jumlah kerang yang berbeda tergantung dari seberapa luasan laut yang digunakan dan media tempel yang disiapkan. Untuk skala besar, satu kali pemanenan bisa menghasilkan 50-70 ember dimana satu ember umumnya setara dengan lima kilogram. Pekerjaan ngitrik inilah yang banyak dikerjakan oleh ibu-ibu dan bahkan anakanak di wilayah tersebut. Dengan demikian, dapat disimpulkan bahwa persepsi perempuan terhadap kegiatan reproduktif tergolong belum baik, artinya pandangan mereka masih bersifat belum sadar gender. Mereka cenderung menyerahkan pekerjaan produktif terkait pembudidayaan kerang hijau kepada laki-laki.

\section{Persepsi terhadap Kegiatan Sosial}

Kegiatan sosial merupakan kegiatan yang terkait dengan kegiatan jasa dan partisipasi politik dalam masyarakat (Hubeis, 2010). Kondisi faktual di lapangan mengungkapkan bahwa kegiatan seperti posyandu, hajatan dan pengajian mayoritas dilakukan oleh istri, sebaliknya kerja bakti dan rapat warga mayoritas dilakukan oleh suami. Hasil rataan skor pada bagian ini adalah 2,36 dan termasuk kategori belum baik, artinya responden belum memahami bahwa perlu ada kesetaraan gender dalam kegiatan sosial, sehingga pemahaman ini masih perlu diperdalam.

Kegiatan Posyandu dan penyuluhan KB memiliki skor yang rendah, yaitu 1,95 dan memang tidak ada yang setuju jika kegiatan ini dilakukan oleh suami. Hal ini berarti bahwa responden berpandangan bahwa kegitan tersebut memang sebaiknya dilakukan oleh istri, di samping itu kegiatan ini memang hampir tidak pernah dihadiri oleh suami.

\section{FAKTOR YANG BERHUBUNGAN DENGAN PERSEPSI RESPONDEN DAN PERANNYA DALAM RUMAH TANGGA}

\section{Faktor Internal}

Faktor internal merupakan faktor yang mencakup karakteristik individu yang dapat mempengaruhi individu tersebut dalam menilai atau mempersepsikan sesuatu (Pangestu, 1995 dalam Aprianto, 2008). Karakteristik individu dalam penelitian ini mencakup usia, tingkat pendidikan, tingkat pendapatan, pekerjaan dan suku. Tidak jauh berbeda dengan usia, tingkat pendidikan dianggap berpengaruh terhadap persepsi seseorang karena ketika mengenyam pendidikan, semakin tinggi pendidikan yang didapatkan maka umumnya cara berpikir dan berpandangan akan semakin luas. Hal ini diasumsikan akan dapat mempengaruhi persepsinya.

Tingkat pendapatan seseorang umumnya akan memperngaruhi kepercayaan diri dan keinginan untuk di-perlakukan setara. Semakin tinggi tingkat pendapatan seseorang maka diasumsikan bahwa keinginan untuk diperlakukan setara juga semakin besar karena ia merasa memiliki hak yang sama setelah dapat berkontribusi besar pada keuangan rumah tangga. Pekerjaan dan suku juga dianggap berpengaruh terhadap persepsi responden karena pengalaman dan latar belakang ia dibesarkan akan membetuk cara pandang dalam dirinya.

\section{Usia}

Responden dalam penelitian ini adalah perempuan yang berperan sebagai istri dalam rumah tangganya. Berdasarkan data yang diperoleh, sebagai besar responden tergolong dewasa pertengahan (31-50 tahun). Uji hubungan menggunakan Uji Korelasi Spearman dan diduga terdapat hubungan yang signifikan antara usia responden dengan persepsinya tentang peran dalam rumah tangga. Hasil Uji Korelasi menunjukkan bahwa usia tidak berhubungan nyata dengan persepsi responden tentang perannya di semua aspek dalam rumah tangga pembudidaya kerang.

Secara keseluruhan, hubungan antara usia dengan persepsi perempuan tentang perannya dalam rumah tangga pembudidaya kerang hijau bersifat tidak berhubungan nyata. Hal ini dibuktikan dari hasil Uji Korelasi Spearman antara usia dengan persepsi tentang peran dalam rumah tangga pembudidaya kerang hijau, nilai $p$ value pada kolom sig.(2-tailed) $0.162>0.05$ level of 
significant $(\alpha)$. Kondisi di lapangan menggambarkan bahwa memang tidak terdapat hubungan yang cukup signifikan antara usia dengan persepsi responden.

Banyak responden yang juga menyatakan bahwa kebiasaanlah yang umumnya membentuk mereka untuk patuh dan taat kepada suami karena mereka beranggapan bahwa memang itulah kodratnya perempuan. Dengan demikian, hipotesis yang menyatakan bahwa terdapat hubungan yang signifikan antara usia responden dengan persepsinya tentang peran dalam rumah tangga pembudidaya kerang hijau tidak terbukti.

\section{Tingkat Pendidikan}

Secara keseluruhan, hubungan antara tingkat pendidikan dengan persepsi perempuan tentang perannya dalam rumah tangga pembudidaya kerang hijau bersifat tidak berhubungan nyata. Dengan demikian, hipotesis yang menyatakan bahwa terdapat hubungan yang signifikan antara tingkat pendidikan responden dengan persepsinya tentang peran dalam rumah tangga pembudidaya kerang hijau tidak terbukti.

Jika dibandingkan dengan program pemerintah, yakni Wajib Belajar 9 Tahun, tingkat pendidikan responden memang terbilang rendah. Pendidikan yang rendah tersebut, yakni rata-rata berkisar 1-6 tahun secara tidak langsung akan mempengaruhi cara pandang mereka mengenai bagaimana sebenarnya posisi perempuan dalam rumah tangga. Hal ini terkait dengan wawasan dan pengetahuan yang mereka miliki. Misalnya, sebagian besar responden beranggapan bahwa pekerjaan reproduktif sepenuhnya tanggung jawab istri, padahal sesunggungnya tanggung jawab tersebut dapat dibagi bersama antara suami dan istri.

Hasil Uji Korelasi memang menunjukkan bahwa usia tidak berhubungan nyata dengan persepsi responden. Berdasarkan pengamatan langsung, hal ini sedikit banyak disebabkan karena rata-rata tingkat pendidikan responden dalam penelitian ini memang terbilang cukup rendah. Hasil ini berbeda dengan data yang didapatkan dari wawancara mendalam dengan salah satu warga yang juga me-miliki usaha budidaya kerang hijau. Ibu Rm (42 tahun) yang mengenyam pendidikan terakhir se-tingkat SMA menyata-kan bahwa menurutnya posisi perempuan dan laki-laki dalam rumah tangga adalah sama. Walaupun ada pem-bagian kerja yang berbeda, namun istri dan suami memiliki hak yang sama untuk mengakses dan meng-ambil keputusan dalam rumah tangga.

\section{Tingkat Pendapatan}

Tingkat pendapatan responden berhubungan dengan perolehan uang yang didapatkan responden perbulan. Dalam melihat hubungan antara tingkat pendapatan dengan persepsi responden, penelitian ini menggunakan Uji Korelasi Rank Spearman dimana diduga terdapat hubungan yang nyata antara tingkat pendapatan dengan persepsi responden.
Secara keseluruhan tingkat pendapatan berhubungan nyata dengan persepsi responden tentang perannya dalam rumah tangga pembudidaya kerang hijau. Pendapatan yang tinggi membentuk cara pandang responden mengenai penghidupan dalam rumah tangganya. Mereka yang memiliki pendapatan tinggi cenderung memandang bahwa perempuan dan laki-laki memiliki posisi yang setara dalam rumah tangga, disebabkan mereka juga turut berperan dalam pemenuhan kebutuhan hidup. Pendapatan yang tinggi juga membuat responden merasa tidak perlu terlalu bergantung dengan suami, artinya mereka memiliki otoritas sendiri dan merasa memiliki hak yang sama dalam pengambilan keputusan.

Di samping itu, responden menganggap bahwa uang pendapatannya adalah uang pribadi yang bisa digunakan jika responden itu sendiri membutuhkan atau meng-inginkan sesuatu tanpa perlu izin dari suami. Dengan demikian, hipotesis yang menyatakan bahwa terdapat hubungan yang signifikan antara tingkat pendapatan responden dengan persepsinya tentang peran dalam rumah tangga pembudidaya kerang hijau terbukti.

\section{Pekerjaan}

Secara keseluruhan, berdasarkan hasil Uji Chi Square ternyata didapatkan bahwa jenis pekerjaan berhubungan nyata dengan persepsi responden tentang perannya dalam rumah tangga pembudidaya kerang. Jenis pekerjaan pada dasarnya berhubungan dengan pendapatan yang didapatkan perbulan. Seperti yang dijelaskan pada subbab sebelumnya, bahwa semakin tinggi pendapatan seseorang maka skor persepsinya akan semakin tinggi. Seorang yang berperan sebagai ibu rumah tangga yang cenderung tidak berpendapatan cenderung berpandang bahwa hidupnya tergantung dengan suami sehingga ia tidak memiliki hak yang setara dalam hal mengakses dan mengambil keputusan dalam rumah tangga. Sebaliknya, pekerjaan yang memiliki pendapatan relatif tinggi, yakni tukang kresit mempengaruhi cara pandang mereka.

Anggapan bahwa istri dan suami memiliki hak yang setara dalam mengakses dan mengambil keputusan dimiliki oleh responden yang berpendapatan relatif tinggi tersebut. Oleh karena korelasi tersebut, dapat ditarik kesimpulan bahwa jenis pekerjaan berhubungan nyata dengan persepsi perempuan tentang perannya dalam rumah tangga pembudidaya kerang hijau dan hipotesis terbukti.

\section{Suku}

Berdasarkan hasil Uji Chi Square dapat disimpulkan bahwa suku tidak berhubungan nyata dengan persepsi di semua aspek, yakni sumberdaya produksi, sumberdaya dan manfaat dalam rumah tangga, kegiatan reproduktif, kegiatan produktif, dan kegiatan sosial. Sehingga didapatkan bahwa suku tidak berhubungan nyata dengan persepsi perempuan terhadap perannya dalam rumah tangga pembudidaya kerang hijau. Hal ini disebabkan responden tidak lagi terlalu memegang budaya sukunya 
masing-masing. Seperti yang diungkap oleh salah satu responden yang bersuku Bugis bahwa dalam suku Bugis laki-laki harus didahulukan dalam semua hal, dimana selain melaut, laki-laki tidak dibebankan tugas lain. Namun, seiring perkembangan zaman dan tuntutan kebutuhan, saat ini jarang ada penduduk yang masih memegang budaya tersebut. Hal serupa terjadi hampir di semua suku, dimana perkembangan zaman dan tuntutan kebutuhan tersebut mengubah cara pandang penduduk terhadap suatu hal. Dengan demikian, hipotesis yang menyatakan bahwa suku responden berhubungan nyata dengan persepsinya tentang peran dalam rumah tangga pembudidaya kerang hijau tidak terbukti.

\section{Faktor Eksternal}

\section{Usia Suami}

Secara keseluruhan, hubungan antara usia suami dengan persepsi perempuan tentang perannya dalam rumah tangga pembudidaya kerang hijau bersifat tidak berhubungan nyata. Kondisi di lapangan menggambarkan bahwa memang tidak terdapat hubungan yang signifikan antara usia suami dengan persepsi responden. Berapa pun usia suami tidak banyak berpengaruh terhadap cara pandang istri karena istri telah memiliki cara sendiri untuk menginterpretasikan hal-hal yang terjadi pada diri dan sekitarnya. Dengan demikian, hipotesis yang menyatakan bahwa terdapat hubungan yang signifikan antara usia suami dengan persepsi responden tentang peran dalam rumah tangga pembudidaya kerang hijau tidak terbukti

\section{Tingkat Pendidikan Suami}

Merasa menjadi pihak yang inferior tersebut secara tidak langsung mempengaruhi cara pandangnya terhadap diri dan sekitarnya. Samovar dan Porter (1985) dalam Mulyana (2001) menjelaskan bahwa salah satu faktor yang mempengaruhi persepsi adalah tabiat manusia dimana pandangan mengenai siapa, bagaimana sifat, dan watak seseorang akan mempengaruhi cara orang tersebut mempersepsi lingkungan fisik dan sosialnya. Dengan demikian, hipotesis yang menyatakan bahwa terdapat hubungan yang signifikan antara tingkat pendidikan suami dengan persepsi responden tentang peran dalam rumah tangga pembudidaya kerang hijau tidak terbukti.

\section{Tingkat Pendapatan Suami}

Kondisi di lapangan menunjukkan bahwa berapapun penghasilan suami, umumnya keuangan tetap diatur oleh istri. Suami tidak banyak ikut campur dalam mengelola keuangan rumah tangga. Dengan kata lain, pendapatan yang diberikan oleh suami tidak berhubungan dengan pembentukan cara pandang istri.

\section{KESIMPULAN DAN SARAN}

\section{Kesimpulan}

Berdasarkan hasil dan pembahasan atas permasalahan dalam penelitian yang telah ditelah dijelaskan sebelumnya, maka kesimpulan yang dapat dirumuskan adalah: pada persepsi tentang akses dan kontrol terhadap sumber daya produksi serta sumber daya dan manfaat dalam rumah tangga, istri cenderung memiliki persepsi yang cukup baik artinya mereka cukup mementingkan adanya kesetaraan gender. Sebaliknya, persepsi perempuan tentang kegiatan reproduktif, produktif dan sosial, istri memiliki persepsi yang cukup negatif dimana mereka memiliki cara pandang yang belum sadar gender. Secara keseluruhan persepsi perempuan terhadap perannya dalam rumah tangga pembudidaya kerang hijau dapat dikatakan cukup negatif, artinya pandangan mereka masih belum sadar gender;

- faktor internal yang signifikan hubungan dengan persepsi perempuan tentang perannya dalam rumah tangga pembudidaya kerang hijau adalah faktor pendapatan dan jenis pekerjaan. Sedangkan usia, tingkat pendidikan dan suku tidak memiliki hubungan yang signifikan dengan persepsi tersebut;

- faktor eksternal yakni usia suami, tingkat pendidikan suami dan tingkat pendapatan suami tidak memiliki hubungan yang signifikan dengan persepsi perempuan terhadap perannya dalam rumah tangga pembudidaya kerang hijau.

\section{Saran}

Berdasarkan hasil pembahasan dan kesimpulan yang telah dijelaskan sebelumnya, maka saran yang dapat disampaikan adalah:

- perlu adanya penyuluhan mengenai wawasan kesetaraan gender;

- diadakannya penyuluhan dan pelatihan terkait hal-hal yang dapat meningkatkan pendapatan istri, seperti pelatihan pengolahan kerang hijau, kerajinan tangan berbahan dasar cangkang kulit kerang, atau usaha lain yang potensial. Hal ini terkait dengan hasil penelitian yang mengungkapkan bahwa semakin tinggi tingkat pendapatan perempuan maka persepsinya juga semakin baik;

- mengadakan kegiatan penyuluhan/pelatihan pada waktu yang dijangkau perempuan seperti siang atau sore sehingga perempuan dapat terlibat aktif pada kegiatan tersebut.

\section{DAFTAR PUSTAKA}

Atkinson, Rita L dkk. 1983. Pengatar Psikologi. Jakarta [ID] : Erlangga.

Dahuri, R., Ginting SP., Rais J., Sitepu MJ. 2001. Pengelolaan Sumber Daya Wilayah Pesisir dan Lautan Secara Terpadu. Jakarta [ID]: Pradnya Paramita. Departemen Pertanian. 1985. Buku Petunjuk Budidaya Kerang Hijau Perna Viridis. Jakarta [ID]: Departemen Pertanian.

Hadiprakoso, A. 2005. Penguatan Peran Gender Dalam Pemberdayaan Keluarga Miskin: Studi Kasus 
Kelompok Dasa Wisma Desa Sudagaran. [Tesis]. Bogor [ID]: Institut Pertanian Bogor.

Handayani, T dan Sugiarti. 2008. Konsep dan Teknik Penelitian Gender. Malang [ID]: UMM Press.

Harahap, M. 2006. Analisis Peran Gender Dalam Pemanfaatan Sumberdaya Perikanan Laut (Studi Kasus Di Kelurahan Panai Hilir Kabupaten Labuhan Batu Propinsi Sumatera Utara). [Tesis]. Bogor [ID]: Institut Pertanian Bogor.

Leavitt, HJ. 1978. Psikologi Manajemen. Jakarta [ID]: Penerbit Erlangga.

Jogianto, HM. 2008. Metodologi Penelitian Sistem Informasi. Yogyakarta [ID]: Andi Offset.

Mosse, JC.1993. Gender dan Pembangunan. Yogyakarta [ID]: Pustaka Pelajar Offset.

Mugnisyah, SS. 2008. Modul Kuliah Pendidikan Orang Dewasa. Bogor [ID]: Sains Komunikasi dan Pengembangan Masyarakat Institut Pertanian Bogor.

Mulyana, D. 2001. Ilmu Komunikasi, Suatu Pengantar. Bandung [ID]: PT. Remaja Rosdakarya.

Nazir, M. 2003. Metode Penelitian. Jakarta [ID]: Ghalia Indonesia.

Nikijuluw, VPH. 2001. Rezim Pengelolaan Sumberdaya Perikanan. Jakarta [ID]: Kerjasama Pusat Pemberdayaan dan Pembangunan Regional dengan PT. Pustaka Cisendo.

Nurlia, A. 2006. Persepsi dan Perilaku Masyarakat dalam Pengelolaan Ekosistem Sub Daerah Aliran Sungai Cikundul. [Skripsi]. Bogor [ID]: Institut Pertanian Bogor.

Prijono, dan Pranarka. 1996. Pemberdayaan, Konsep dan Implementasi. Jakarta [ID]: CSIS.

Rakhmat, J. 2003. Psikologi Komunikasi. Bandung [ID]: PT. Remaja Rosdakarya. Rusli S. 1995. Pengantar Ilmu Kependudukan. Jakarta [ID]: Lembaga Penelitian, Pendidikan, dan Penerangan Ekonomi dan Sosial.

Saruan, C. 2000. Studi Gender pada Rumah Tangga Nelayan dalam Pengelolaan Sumberdaya Pesisir dan Lautan. [Tesis]. Bogor [ID]: Institut Pertanian Bogor.

Sarwono, J. 2006. Metode Penelitian Kuantitatif dan Kualitatif. Yogyakarta [ID]: Graha Ilmu.

Sarwono, Wirawan S. 1999. Psokologi Sosial: Individu dan Teori-Teori Psikologi Sosial. Jakarta [ID]: Balai Pustaka.

Satria, A. 2002. Pengantar Sosiologi Mayarakat Pesisir. Jakarta [ID]: Cisendo. Singarimbun M dan Effendi
S. 2006. Metode Penelitian Survei. Jakarta [ID]: Pustaka LP3ES.

Hubeis, AVS. 2010. Pemberdayaan Perempuan dari Masa ke Masa. Bogor [ID]: IPB Press

Walgito, B. 2001. Psikologi Sosial: Suatu Pengantar. Yogyakarta [ID]: Ar-Ruzz Media. 